\title{
Karakteristik Iklim dan Tanah Vulkanis di Sisi Barat Gunung Api Ijen Jawa Timur Sebagai Dasar Penentu Pengelolaan Varietas Tanaman Padi (Oriza sativa L.)
}

\section{Climate Characteristics and Volcanic Soils on The West Side of Mount Ijen, East Java as The Basis of Determining The Management of Rice Varieties (Oriza sativa L.)}

\author{
Basuki $^{*}$, Sukron Romadhona ${ }^{1}$, Vega Kartika Sari ${ }^{1}$, dan Iqbal Erdiansyah ${ }^{2}$ \\ ${ }^{1}$ Fakultas Pertanian. Universitas Jember. Jl. Kalimantan No.1 Kampus Tegal Boto, Jember \\ ${ }^{2}$ Jurusan Produksi Pertanian. Politeknik Negeri Jember. Jl. Raya Mastrip PO BOX 164, Jember \\ *E-mail : basuki@unej.ac.id
}

\begin{abstract}
The suitability of typical rice varieties in Tegalampel Sub-District, Bondowoso District. The need for rice is increasing every year. Rice production is inseparable from paddy production in the field. Paddy production on the field will be optimal if the variety matches the soil and land characteristics. This research is an exploratory study to evaluate the suitability of the typical location of paddy varieties in Tegalampel Sub-District, Bondowoso District. The research was conducted in August-December 2020 in Tegalampel District, Jember Regency, and soil analysis at the Soil Fertility Laboratory of the University of Jember. The research method uses a survey method which is divided into 3 stages: literature study, field survey, and data analysis. The results showed Tegalampel Sub-District has the potential to be planted with paddy divided into 3 land uses with a height of $<700 \mathrm{~m}$ asl with rainfall $<2000 \mathrm{~mm} /$ year, namely irrigated rice fields, rain-fed rice fields, and dry fields / dry land. Suitability of rice varieties for irrigated rice fields namely Ciherang, Inpari 1, Inpari 6 Jete, Mekongga by 16.60\%; suitability of rice varieties for rain-fed rice fields are varieties Inpari 10, Inpari 12, Inpari 13, Inpari 18, Inpari 19, Inpari 20, Inpari 38, Inpari 39, Inpari 40, Inpari 41, Dodokan, Silugonggo by $26.64 \%$; and suitability of rice varieties for dry fields / dry land, namely Inpago 5, Inpago 8, Inpago 9, Inpago 10, Inpago 11, Inpago 12 by $26.35 \%$.
\end{abstract}

Keywords: paddy, varieties, suitability, survey, typical location

Disubmit : 16 Maret 2021, Diterima: 19 April 2021,Disetujui : 31 Agustus 2021

\section{PENDAHULUAN}

Kabupaten Bondowoso berada di daerah vulkanik dengan di kelilingi oleh Gunung Api purba Iyang, dan Gunung Api Argopuro. Gunung Api purba Iyang berada di sebelah selatan kabupaten sekarang menjelma menjadi deretan gunung aktif muda seperti Gunung Api Raung, Gunung Api Rante, dan Gunung Api Suket. Gunung Api Ijen berada di perbatasan 2 kabupaten yaitu Kabupaten Banyuwangi, dan Kabupaten Bondowoso. Menurut (Zaennudin et al., 2012), Gunung Api Ijen erupsi sudah lebih dari 12 kali mulai dari tahun 1791, 1817, 1917, 1936,1952, 1962, 1976, 1991, 1993, 1999, 2000, 2001. Bahan vulkanik yang dikeluarkan mempengaruhi perkembangan tanah dan kesuburan tanah (Anda, Markus; Sarwani, 2012). Abu vulkanik mengandung $0,29 \% \mathrm{P} 2 \mathrm{O} 5,2,89 \% \mathrm{MgO}, 2,10 \% \mathrm{~K} 2 \mathrm{O}, 8,96 \% \mathrm{CaO}$ (Wahyuni et al, 2012). Secara fisiografi, 
keberadaan gunung api Ijen juga mempengaruhi sistem pertanian yang ada di kaki gunung yang berada di Kabupaten Bondowoso. Keberadaan gunung api tersebut menyebabkan Kabupaten bondowoso berada pada bentukan lahan berbukit-bergunung yang secara sistem pertanian mempengaruhi kesesuaian komoditas tanaman pertanian. Pengelolaan lahan untuk budidaya tanaman dengan menerapkan teknologi yang sesuai menuntut informasi terkait kesesuaian antara karakteristik lahan dengan karakteristik komoditas tanaman. Pengelolaan lahan dan tanah di wilayah vulkanik perlu di dasarkan pada evaluasi kesesuaian lahan agar di peroleh sistem pertanian yang berkelanjutan(Sukarman, et al, 2020).

Beras merupakan bahan pangan pokok yang mempunyai peran penting di Indonesia (Handani et.al., 2017). Permintaan kebutuhan beras dari tahun ketahun meningkat, sejalan dengan peningkatan jumlah penduduk. Padi tumbuh dan berkembang dipengaruhi temperature, ketersediaan air, media perakaran yang sesuai, retensi hara, bahaya erosi, banjir (Tampubolon et al., 2015). Pada tahun 2019, produksi beras nasional sebesar 31,31 juta ton, menurun 7,75\% dibandingkan tahun 2018 (Yuniartha, 2020). Menurut BPS (2019), produksi beras pada tahun 2019 masih surplus sebesar 1,53 juta ton. Provinsi Jawa Timur merupakan salah satu pemasok beras nasional dengan luas areal sawah yang ditanami padi tahun 2017 sebesar 2.136.412,0 hektare (BPS, 2018). Kabupaten di Jawa Timur dengan lahan sawah terluas yang ditanami padi berada pada Kabupaten Jember (161.640,3 hektare), dan Kabupaten Banyuwangi (120.430,3 hektare). Selain dua kabupaten yang berada didaerah tapal kuda tersebut, Kabupaten Bondowoso mempunyai potensi yang tinggi sebagai sumber pemasok beras nasional. Berdasarkan data dari BPS tahun 2018, mulai tahun 2013 areal lahan yang ditanami padi dari tahun ke tahun meningkat. Tahun 2013, luas areal lahan yang ditanami padi di Kabupaten Bondowoso sebesar 57.727 hektare, tahun 2014 sebesar 56.600 hektare, tahun 2015 sebesar 68.609 hektare, tahun 2016 sebesar 72.104,2 hektare, dan tahun 2017 meningkat menjadi 79.018,4 hektare. Perluasan lahan tersebut didukung oleh program pemerintah melalui pemanfaatan lahan kering dibawah tegakan dan lahan tidak produktif menjadi lahan sawah lahan kering (BBPPMBTPH, 2021).

Kabupaten Bondowoso terbagi atas 23 kecamatan, dan areal lahan di 22 kecamatan ditanami komoditas padi. Produktifitas padi di Kabupaten Bondowoso per hektare rata-rata 6,15 ton. Produktifitas padi per hektare dari 7 kecamatan masih dibawah rata-rata kabupaten, salah satunya Kecamatan Tegalampel. Rendahnya produksi disebabkan oleh varietas padi yang ditanam tidak bersetifikasi dan tidak sesuai dengan lahan yang ditanami. Rata-rata produksi padi Kecamatan Tegalampel yaitu sebesar 5,57 ton/hektar (BPS, 2019). Hasil dari dat BPS, Kecamatan Tegalampel mempunyai potensi untuk mendukung target produksi propinsi, karena tanahnya merupakan tanah yang subur dengan kandungan mineral dan nutrisi yang tinggi tetapi masyarakat belum mengetahui varietas mana yang sesuai sehingga produksi belum sesuai. Produktifitas padi per hektare di Kecamatan Tegalampel dibawah rata-rata disebabkan oleh ketersediaan air irigasi tidak mencukupi, dan proses budidaya sebagian besar dipengaruhi oleh iklim. Padi dalam siklus hidup membutuhkan air $8.800 \mathrm{~m}^{3}$ sistem konvensional, dan $6.840 \mathrm{~m}^{3}$ sistem SRI (Fuadi et al., 2016). Peningkatan produktifitas tanaman padi di Kecamatan Tegalampel sangat penting untuk mendukung produktifitas rata-rata kabupaten, propinsi, serta nasional. Penelitian ini bertujuan untuk mengkaji dan memetakan kesesuaian varietas tanaman padi yang spesifik lokasi berdasarkan penggunaan lahan dan karakteristik lahan di Kabupaten Bondowoso.

\section{METODE PENELITIAN}

Penelitian dilaksanakan di Kabupaten Bondowoso dan Labotratorium Kimia \& Kesuburan Program Studi Ilmu Tanah Fakultas Pertanian Universitas Jember sejak bulan Agustus-Desember tahun 2020. Bahan penelitian yang digunakan antara lain data curah hujan (2012-2019) yang didapat dari LAPAN, data penggunaan lahan dari klasifikasi citra satelit, sampel tanah pewakil, bahan survai lapang, dan bahan kemikalia analisis di laboratorium. Sampel dianalisis di laboratorium dengan parameterseperti Tabel 1., dengan kemikalia yang digunakan antara lain $\mathrm{NaHCO}_{3}$, Amonium asetat, Asam Sulfat, $\mathrm{NaOH}$. Alat yang digunakan 
dalam penelitian ini antara lain GPS, bor tanah, seperangkat alat pengolah peta (Sas Planet, Geomatica, ArcGis), klinometer, seperangkat alat analisis tanah di laboratorium.

Metodologi. Penelitian ini merupakan penelitian diskripsi eksplorasi, metode penelitian yang digunakan yaitu survei dan matching. Tahap penelitian terbagi atas pra survei, survei lapang, dan analisis data. Penelitian pra survai meliputi mengumpulkan dan mengkompilasi bahan penelitian menjadi pembuatan peta kerja diantaranya peta tanah (BBSDLP 2018), peta topografi (pengolahan data raster DEM dari SRTM). Kegiatan survei lapang meliputi pengambilan sampel tanah dan data lapang. Kegiatan analisis data meliputi analisis curah hujan, analisis laboratorium meliputi 10 variabel parameter tanah (Tabel 1.), analisis spasial, dan analisis matching.

Tabel 1. Parameter variabel karakteristik tanah yang diamati

\begin{tabular}{llll}
\hline No. & \multicolumn{1}{c}{ Variabel } & \multicolumn{1}{c}{ Metode } & \multicolumn{1}{c}{ Sumber Referensi } \\
\hline 1 & Potensial Hidrogen $(\mathrm{pH})$ & Hidrometer & (Basuki \& Vega, 2020) (Basuki, 2020) \\
2 & Carbon $(\mathrm{C})$ Organik & Walkey \& Black & (Basuki, et al., 2015) \\
3 & Nitrogen $(\mathrm{N})$ Total Tanah & Kjeldahl & (Sukri et al., 2020) \\
4 & Pospat Tersedia $\left(\mathrm{P}_{2} \mathrm{O}_{5}\right)$ & Olsen & (Basuki, et al., 2015) \\
5 & Kalium $(\mathrm{K})$ & Ekstrak Amonium Asetat pH 7 & (Basuki, et al., 2015) \\
6 & Calsium $(\mathrm{Ca})$ & Ekstrak Amonium Asetat pH 7 & Ballitan (2009) \\
7 & Magnesium $(\mathrm{Mg})$ & Ekstrak Amonium Asetat pH 7 & Ballitan (2009) \\
8 & Natrium $(\mathrm{Na})$ & Ekstrak Amonium Asetat pH 7 & Ballitan (2009) \\
9 & Kapasitas Tukar Kation (KTK) & Ekstrak Amonium Asetat pH 7 & Ballitan (2009) \\
10 & Kejenuhan Basa (KB) & Ekstrak Amonium Asetat pH 7 & Ballitan (2009) \\
\hline
\end{tabular}

Olah data spasial dengan mengolah foto citra satelit resolusi tinggi dengan bantuan software pemetaan (SAS Planet, Geomatica, dan Arcgis) untuk mendapatkan data kontur yang selanjutnya untuk analisis peta topografi. Analisis data Matching yaitu memadukan karakteristik biotik dan abiotik daerah penelitian dengan kebutuhan karakteristik tiap jenis varietas tanaman padi untuk tumbuh secara optimal. Dasar kesesuaian varietas tanaman padi dengan kondisi lingkungan (ketinggian tempat, dan penggunaan lahan) berdasarkan petunjuk pelaksanaan budidaya padi lahan kering tahun 2020 oleh Direktorat Jenderal Tanaman Pangan Kementerian Pertanian dan deskripsi varietas unggul baru padi tahun 2019.

\section{HASIL DAN PEMBAHASAN}

Kondisi Geografis dan Iklim. Kecamatan Tegalampel Kabupaten Bondowoso berada di Provinsi Jawa Timur pada posisi $113^{\circ} 47^{\prime}-113^{\circ} 57^{\prime}$ BT, dan $7^{\circ} 45^{\prime}-7^{\circ} 49^{\prime}$ LS. Luas wilayah Kecamatan Tegalampel berkisar 3164,5 hektare, terbagi atas beberapa penggunaan lahan diantaranya sawah, tegal, rumah/pekarangan, dan penggunaan lain (Tabel 2.). Hasil pengamatan studi pustaka, sejak tahun 2012-2018 penggunaan lahan di kecamatan ini tidak berubah, penggunaan lahan sawah lebih bersifat stagnan dan tidak terdapat penambahan. Hasil survei dan pengamatan lapang melalui wawancara dengan 4 kelompok tani yang masing-masing anggota tiap kelompok 15-25 anggota (tiap anggota memiliki luas antar 0,1-0,5 hektar), dan identifikasi lapang, jenis padi yang dibudidayakan merupakan jenis padi sawah dengan karakteristik hidupnya membutuhkan lahan tergenang/berair. Pemanfaatan lahan yang mampu ditanami padi dengan karakteristik tersebut tidak begitu luas, 25,66\% luas total Kecamatan Tegalampel. Menurut (Sahulata, 2017), masyarakat masih berpangku pada jenis padi dilahan irigasi, sedangkan pemanfaatan lahan tidur berupa lahan tegal, dan lahan terbuka lainnya sebagai lahan budidaya padi lahan kering belum termanfaatkan secara optimal.

Budidaya padi tidak terlepas dari pengaruh iklim terutamanya curah hujan (Sugiarto, 2020). Menurut Ritung et al. (2011), perbedaan padi sawah, padi lebak, padi tadah hujan, dan padi gogo terletak pada kebutuhan air. Padi sawah dan padi lebak dalam siklus hidup membutuhkan air irigasi dan membutuhkan 
Basuki, B., dkk : Karakteristik Iklim dan Tanah Vulkanis di Sisi Barat Gunung Api Ijen Jawa Timur...

kondisi tergenang, sedangkan padi gogo dan padi tadah hujan membutuhkan air dengan interval tertentu dalam buan-bulan pertumbuhannya, tetapi tidak harus tergenang. Djaenuddin et al. (2003) dalam Sinaga et al. (2014) mengungkapkan bahwa jumlah curah hujan yang dibutuhkan jenis padi tadah hujan dalam fase pertumbuhannya membutuhkan curah hujan berbeda, pada bulan 1, 2, 3 sebesar 175 - $500 \mathrm{~mm}$, sedangkan untuk bulan ke- 4 sebesar 50-300 mm. Padi tadah hujan, kelas S1 dalam evaluasi lahan membutuhkan kondisi wilayah iklim Oldeman B2, B3, dan C2, sedangkan padi gogo kelas S1 evaluasi lahan membutuhkan iklim C2, C3, D2, D3 (Ritung et al., 2011). Curah hujan kurun waktu 8 tahun (2012-2019) memiliki rata-rata $1375 \mathrm{~mm} /$ tahun, dan rata-rata per bulan $115 \mathrm{~mm}$ (Tabel 3).

Tabel 2. Tinggi Tempat dan Penggunaan Lahan Kecamatan Tegalampel Kabupaten Bondowoso

\begin{tabular}{lcccccc}
\hline \multicolumn{1}{c}{$\begin{array}{c}\text { Desa/ } \\
\text { Kelurahan }\end{array}$} & $\begin{array}{c}\text { Tinggi Tempat } \\
(\mathrm{m} \mathrm{dpl})\end{array}$ & Sawah & Tegal dan Ladang & Bangunan & Lain & Total \\
\cline { 3 - 7 } Karanganyar & 285 & 249 & 150.8 & 30.9 & 3.7 & 434.4 \\
Sekarputih & 240 & 212 & 40.4 & 48.0 & 34.6 & 335.0 \\
Tegalampel & 276 & 101 & 107.2 & 12.1 & 10.4 & 230.7 \\
Mandiro & 277 & 136 & 286.6 & 35.0 & 25.4 & 483.0 \\
Tanggulangin & 320 & 26 & 298.2 & 21.5 & 28.1 & 373.8 \\
Klabang & 413 & 75 & 517.5 & 37.2 & 15.8 & 645.5 \\
Klabangagung & 312 & 13 & 215.0 & 17.2 & 18.5 & 263.7 \\
Purnama & 508 & 0 & 278.9 & 28.6 & 90.9 & 398.4 \\
\hline \multicolumn{1}{c}{ Total } & & 812 & 1894.6 & 230.5 & 227.4 & 3164.5 \\
\hline
\end{tabular}

Sumber: Kecamatan dalam Angka Tahun 2012-2018

Oldeman mengklasifikasikan tipe iklim berdasarkan bulan basah (BB), dan bulan kering (BK), bulan basah bila curah hujan per bulan lebih dari $200 \mathrm{~mm}$, dan bulan kering curah hujan per bulan dibawah $100 \mathrm{~mm}$ (Nasution and Nuh, 2018) Hasil analisis berdasarkan iklim Oldeman, Kecamatan Tegalampel mempunyai BB 3-4 bulan, dan BK 6-7 bulan. Berdasarkan kriteria tersebut, Kecamatan Tegalampel terbagi atas Iklim D3-D4 (Mahubessy, 2014). Berdasarkan klasifikasi iklim oldeman tipe iklim D3-D4 dapat diartikan bahwa lahan dapat diperuntukkan untuk budidaya tanaman padi terutama padi sawah hanya 1 kali dalam setahun dan tergantung ketersediaan air irigasi.

Tabel 3. Curah Hujan 8 Tahun (2012-2019) Kecamatan Tegalampel Kabupaten Bondowoso.

\begin{tabular}{ccccccccccccccc}
\hline $\begin{array}{c}\text { Tahun/ } \\
\text { Bulan }\end{array}$ & Jan & Feb & Mar & Apr & Mei & Jun & Jul & Agt & Sep & Okt & Nov & Des & Jumlah & Rata-rata \\
\hline 2012 & 348 & 146 & 196 & 50 & 97 & 12 & 3 & 0 & 1 & 3 & 5 & 235 & 1096 & 91 \\
2013 & 406 & 249 & 208 & 205 & 171 & 215 & 115 & 0 & 2 & 0 & 173 & 243 & 1987 & 166 \\
2014 & 284 & 266 & 130 & 136 & 48 & 1 & 22 & 16 & 0 & 4 & 3 & 222 & 1132 & 94 \\
2015 & 246 & 217 & 190 & 235 & 62 & 0 & 0 & 8 & 0 & 0 & 4 & 145 & 1107 & 92 \\
2016 & 245 & 285 & 102 & 119 & 123 & 101 & 99 & 3 & 33 & 127 & 110 & 300 & 1647 & 137 \\
2017 & 337 & 201 & 172 & 146 & 106 & 130 & 11 & 13 & 0 & 6 & 236 & 198 & 1556 & 130 \\
2018 & 406 & 344 & 234 & 19 & 8 & 28 & 0 & 7 & 2 & 0 & 62 & 170 & 1280 & 107 \\
2019 & 396 & 204 & 309 & 171 & 5 & 0 & 12 & 1 & 3 & 0 & 1 & 96 & 1198 & 100 \\
\hline Rata-rata & 334 & 239 & 193 & 135 & 78 & 61 & 33 & 6 & 5 & 18 & 74 & 201 & 1375 & 115 \\
\hline
\end{tabular}

Sumber: Lapan (2020)

Karakteristik Lahan dan Tanah. Kecamatan Tegalampel berada di kaki Gunung Ijen, dan Gunung Raung, sehingga tanah yang terdapat di kecamatan ini dipengaruhi sebagian besar aktifitas kedua gunung tersebut. Fisiografi lahan volkan dengan relief datar-berombak. Fisiografi lereng di Kecamatan Tegalampel 
sebagian besar dalam kategori landai (40,88\%), 28,67\% dalam kategori bergelombang, 25,83\% dalam kategori topografi lahan curam, dan 4,63\% topografi lahan berbukit. Bahan induk didominasi oleh bahan vulkanik dengan material utama bersifat basa. Bahan induk tanah menentukan karakteristik kimia tanah yang terbentuk (Suratman, Hikmatullah and Sulaiman, 2018) sedangkan fisiografi lereng berpengaruh terhadap kondisi tata irigasi atau sebaran air pengairan untuk budidaya (Yusuf et al., 2018) Topografi lahan curam di Kecamatan Tegalampel peruntukan lahan/ penggunaan lahan hutan. Peta topografi Kecamatan Tegalampel disajikan pada Gambar 1.

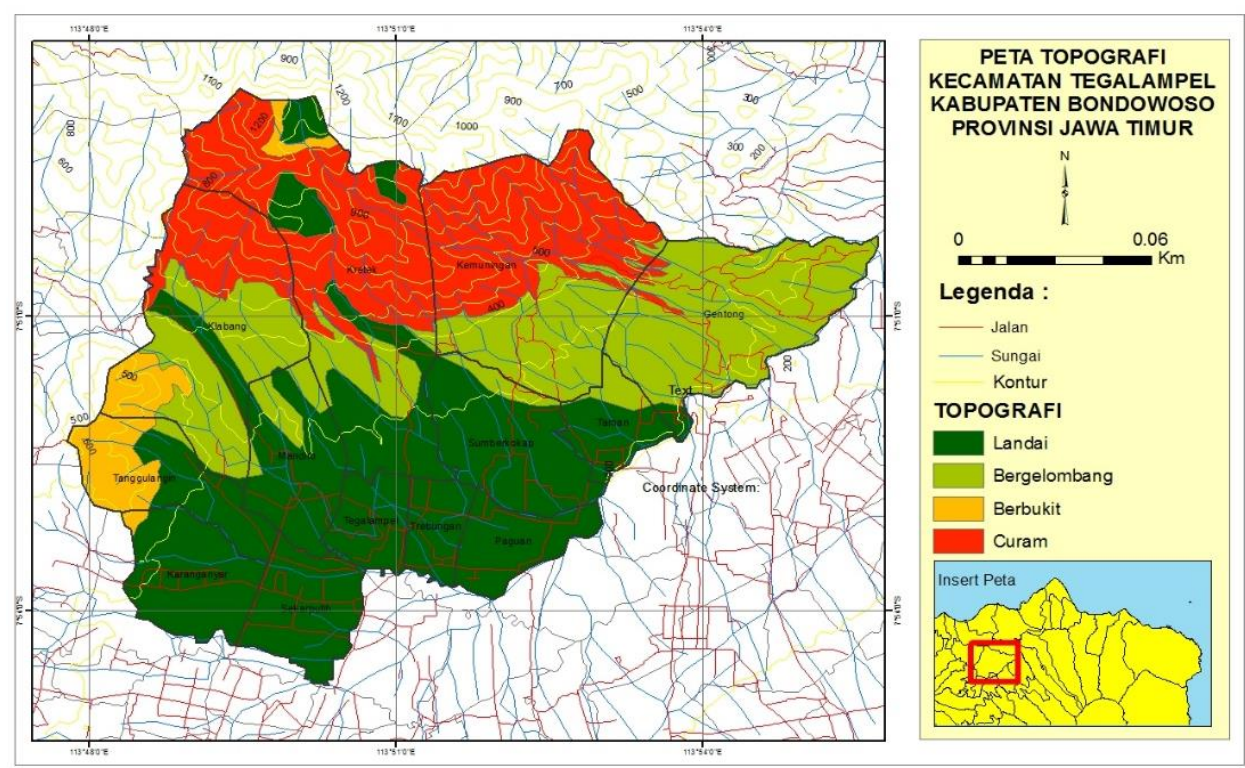

Gambar 1. Peta Topogafi Kecamatan Tegalampel Kabupaten Bondowoso

Jenis tanah yang terbentuk menurut klasifikasi Taksonomi USDA yaitu Haplustepts dengan bahan induk yang bersifat basa seperti abu/pasir dengan tuf volkan intermedier sampai basis. Tanah yang terbentuk dari abu dan tuf volkan mempunyai tingkat karakteristik tanah yang unik, dan mendukung dari segi kimia tanah untuk budidaya pertanian (Prasetyo et al., 2009). Hasil analisis parameter karakteristik tanah Kecamatan Tegalampel sebagaimana tampak pada Tabel 4.

Tabel 4. Hasil Analisis Parameter Karakteristik Tanah Kecamatan Tegalampel

\begin{tabular}{clrcc}
\hline No. & \multicolumn{1}{c}{$\begin{array}{c}\text { Parameter Karakteristik } \\
\text { Tanah }\end{array}$} & Nilai & Satuan & Harkat \\
\hline 1 & Potensial Hidrogen $(\mathrm{pH})$ & 6.64 & - & Netral \\
2 & Carbon Organik & 0.48 & $\%$ & Sangat Rendah \\
3 & Nitrogen Total Tanah & 0.043 & $\%$ & Sangat Rendah \\
4 & Pospat Tersedia $\left(\mathrm{P}_{2} \mathrm{O}_{5}\right)$ & 35.43 & $\mathrm{ppm}$ & Tinggi \\
5 & Kalium $\left(\mathrm{K}_{2} \mathrm{O}\right)$ & 136.69 & $\mathrm{ppm}$ & Sedang \\
6 & Calsium $(\mathrm{Ca})$ & 8.72 & $\mathrm{Cmol}(+) \mathrm{Kg}$ & Sedang \\
7 & Magnesium $(\mathrm{Mg})$ & 3.84 & $\mathrm{Cmol}(+) \mathrm{Kg}$ & Tinggi \\
8 & Natrium $(\mathrm{Na})$ & 0.11 & $\mathrm{Cmol}(+) \mathrm{Kg}$ & Rendah \\
9 & Kapasitas Tukar Kation & 14.55 & $\mathrm{Cmol}(+) \mathrm{Kg}$ & Rendah \\
10 & Kejenuhan Basa $(\mathrm{KB})$ & 89 & - & Sangat Tinggi \\
\hline
\end{tabular}

Sumber : Hasil analisis laboratorium

Keterangan: Harkat berdasarkan kriteria Pusat Penelitian Tanah Bogor (2009)

Sampling tanah diambil dari 7 desa di Kecamata Tegalampel yaitu DEsa Karanganyar, Desa Klabang, Desa Kabang Agung, Desa Mandiro, Desa Sekarputih, Desa Tanggulangin, Desa Tegalampel. Tiap desa 
Basuki, B., dkk : Karakteristik Iklim dan Tanah Vulkanis di Sisi Barat Gunung Api Ijen Jawa Timur...

diambil 2 titik sampel sehingga dari 1 kecamatan didapat 14 sampel yang dikompositkan menjadi satu. Tabel 4. menunjukkan kandungan pospat, dan magnesium di Kecamatan Tegalampel dalam kategori tinggi, kedua unsur tersebut merupakan unsur yang penting yang mampu mendukung proses fotosintesis sehingga proses generatif dan produksi hasil mampu secara optimal (Subhan \& Nurtika, 2004; )(Supriyadi, 2019). Menurut Dobermann dan Fairhurst (2000) dalam Yuniarti et al., 2019, setiap 1 ton padi menyerap unsur hara sebesar $14,7 \mathrm{~kg} / \mathrm{ha} ; 2,6 \mathrm{~kg}$ P/ha; dan 14,5 kg K/ha. Parameter bahan organik dan nitrogen dalam kategori rendah, sehingga untuk mendukung pertumbuhan tanaman padi harus melalui pemupukan. Potensial hidrogen dalam kategori netral, sehingga keracunan unsur hara mikro seperti Fe sangat kecil, $\mathrm{pH}$ tanah tersebut didukung oleh kejenuhan basa yang tinggi. Menurut (Suardjana et al., 2016) status kesuburan tanah sangat menentukan anjuran pengelolaan terutamanya pemberian dosis dan jenis pupuk yang akan diaplikasikan.

Kesesuaian Varietas Tanaman Padi. Tingkat kesesuaian varietas padi tidak terlepas dari preferensi petani, wilayah, jenis padi, ketersediaan benih padi dipasaran, dan peranannya terhadap distribusi varietas di tiap wilayah (Giamerti \& Fauzan, 2018), (Nasution and Nuh, 2018). Ruskandar et al., (2008), menyatakan bahwa hal yang berpengaruh cukup besar terhadap preferensi minat petani adalah produktivitas, fisik tanaman, rasa nasi, tekstur nasi, dan ketahanan hama penyakit, sedangkan menurut Djaenuddin et al. (2003; 2011), kesesuaian lahan tanaman padi dibedakan menjadi tiga yaitu kesesuaian lahan tanaman padi irigasi, kesesuaian lahan tanaman padi tadah hujan, dan kesesuaian lahan tanaman padi lahan kering. Kesesuaian lahan tanaman padi tadah hujan, curah hujan per bulan yang dibutuhkan untuk bulan ke- 1, 2, dan 3 minimal 175, serta bulan ke-4 minimal $50 \mathrm{~mm}$ (Sinaga et al, 2014), (Rizkayanti, Syam and Mahi, 2014), (Nasution and Nuh, 2018), (Dulbari et al., 2018), (Ahadiyat et al., 2020).

Kabupaten Bondowoso terutama Kecamatan Tegalampel, karakteristik tanah produktif yang digunakan oleh petani dilihat dari kondisi iklim dan lereng terbagi atas 2 tipe penggunaan lahan. Dua tipe penggunaan lahan antara lain lahan basah, dan lahan kering. Lahan basah terbagi atas lahan optimal (lahan irigasi), dan lahan sub optimal (lahan tadah hujan), sedangkan lahan kering meliputi tegalan, dan ladang (Tabel 5) (Mulyani, et.al. 2017). Sebaran penggunaan lahan Kecamatan Tegalampel Kabupaten Bondowoso sebagaimana disajikan pada Gambar 2, presentase penggunaan lahan sebagai berikut 7,62\% untuk pemukiman, $16,60 \%$ sawah irigasi, 26,64\% sawah tadah hujan, 26,35 tegalan, dan sisanya lahan konservasi dalam bentuk hutan lindung.

Tabel 5. Matching tipologi lahan dan karakteristik dengan jenis varietas tanaman padi

\begin{tabular}{|c|c|c|c|c|}
\hline No. & $\begin{array}{l}\text { Penggunaan } \\
\text { Lahan }\end{array}$ & Karakteristik Lahan & $\begin{array}{l}\text { Persentase } \\
\text { Luas }(\%)\end{array}$ & Jenis Varietas \\
\hline 1. & Sawah Irigasi & $\begin{array}{l}\text { Dataran rendah }(<700 \mathrm{mdpl}) \text {, } \\
\text { iklim kering } \quad(<2000 \\
\text { mm/tahun })\end{array}$ & 16,60 & $\begin{array}{l}\text { Ciherang, Inpari 1, Inpari } 6 \text { Jete, } \\
\text { Mekongga }\end{array}$ \\
\hline 2. & $\begin{array}{l}\text { Sawah Tadah } \\
\text { Hujan }\end{array}$ & $\begin{array}{l}\text { Dataran Rendah }(<700 \mathrm{mdpl}) \text {, } \\
\text { iklim kering } \quad(<2000 \\
\mathrm{mm} / \text { tahun })\end{array}$ & 26,64 & $\begin{array}{l}\text { Inpari 10, Inpari 12, Inpari 13, Inpari } \\
\text { 18, Inpari 19, Inpari 20, Inpari 38, Inpari } \\
\text { 39, Inpari 40, Inpari 41, Dodokan, } \\
\text { Silugonggo }\end{array}$ \\
\hline 3. & Tegalan & $\begin{array}{l}\text { Dataran Rendah }(<700 \mathrm{mdpl}) \text {, } \\
\text { iklim kering } \quad(<2000 \\
\text { mm/tahun })\end{array}$ & 26,35 & $\begin{array}{l}\text { Inpago 5, Inpago 8, Inpago 9, Inpago 10, } \\
\text { Inpago } 11 \text {, Inpago } 12\end{array}$ \\
\hline
\end{tabular}

Sumber: Referensi analisis BB Padi, Litbang Pertanian 2020.

Menurut Ahadiyat \& Ardiansyah (2020), produktifitas varietas padi sangat tergantung dari tipologi/ penggunaan lahan, dan karakteristik lahan. Gunung Iyang-Ijen merupakan gunung penghasil sulfur. Sulfur merupakan unsur yang mendukung pertumbuhan padi dengan produksi 5 ton/ha (Wihardjaka dan Poniman, 
2015). Matching tipologi lahan dan karakteristik dengan jenis varietas tanaman padi sebagaimana tampak pada Tabel 5. menunjukkan bahwa Kecamatan Tegalampel mempunyai potensi untuk budidaya padi terbagi atas tiga penggunaan lahan dengan karakteristik lahan dataran rendah dengan ketinggian $<700$ mdpl dengan curah hujan $<2000 \mathrm{~mm} / \mathrm{tahun}$ yaitu sawah irigasi, sawah tadah hujan, dan tegalan/ lahan kering.

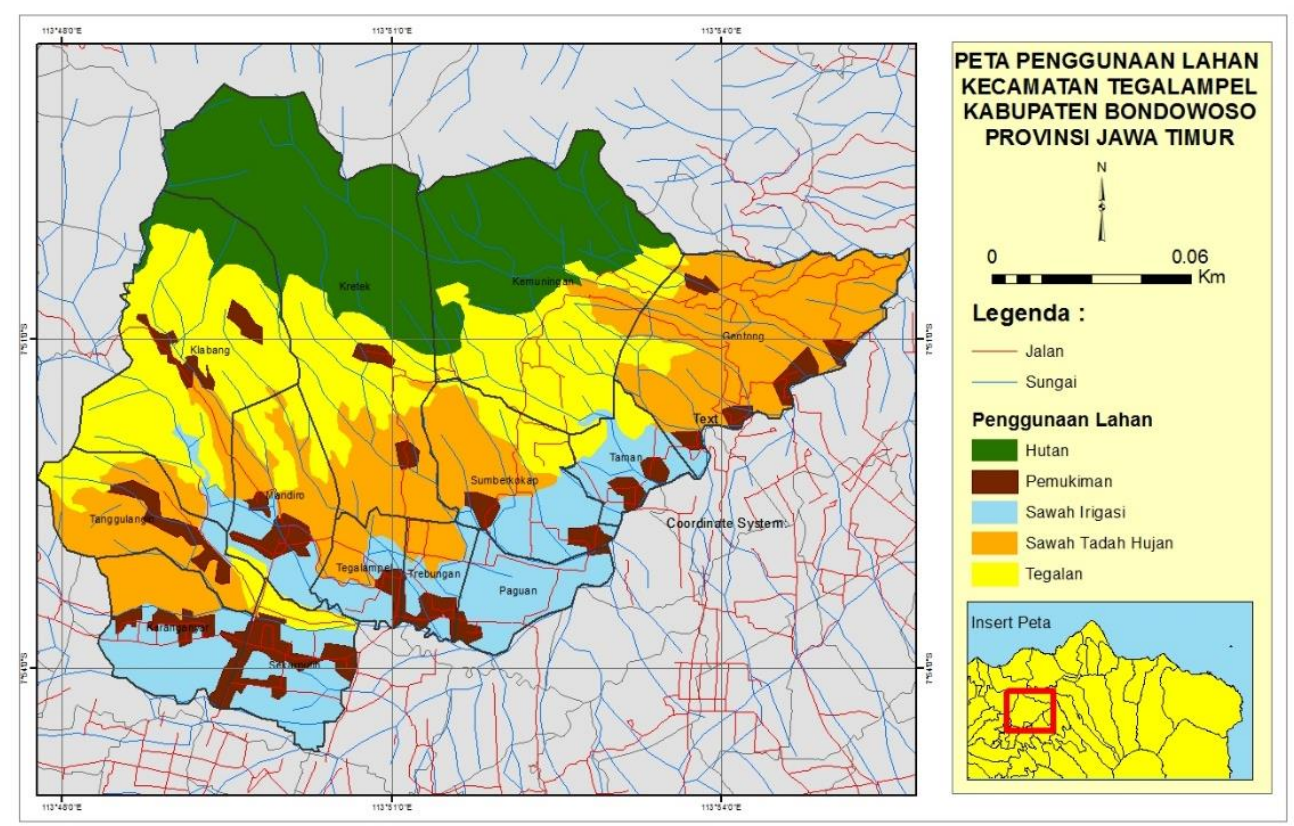

Gambar 2. Peta Penggunaan Lahan Kecamatan Tegalampel Kabupaten Bondowoso

Kesesuaian varietas pada sawah beririgasi dengan ketinggian $<700$ mdpl dengan curah hujan $<2000$ $\mathrm{mm} /$ tahun dengan luas wilayah sebesar 16,60\% dari total luas Kecamatan Tegalampel yaitu Ciherang, Inpari 1, Inpari 6 Jete, Mekongga. Kesesuaian varietas pada sawah tadah hujan dengan dengan luas wilayah sebesar 26,64\% dari total luas Kecamatan Tegalampel yaitu Inpari 10, Inpari 12, Inpari 13, Inpari 18, Inpari 19, Inpari 20, Inpari 38, Inpari 39, Inpari 40, Inpari 41, Dodokan, Silugonggo. Kesesuaian varietas pada tegalan/lahan kering dengan ketinggian $<700 \mathrm{mdpl}$ dengan curah hujan $<2000 \mathrm{~mm} /$ tahun dengan luas wilayah sebesar 26,35\% dari total luas Kecamatan Tegalampel yaitu Inpago 5, Inpago 8, Inpago 9, Inpago 10, Inpago 11, Inpago 12

\section{KESIMPULAN}

Kecamatan Tegalampel Kabupaten Bondowoso berpotensi untuk ditanami padi. Kesesuaian varietas padi untuk lahan sawah irigasi yaitu varietas Ciherang, Inpari 1, Inpari 6 Jete, Mekongga sebesar 16,60\%; lahan sawah tadah hujan yaitu varietas Inpari 10, Inpari 12,Inpari 13, Inpari 18, Inpari 19, Inpari 20, Inpari 38, Inpari 39, Inpari 40, Inpari 41, Dodokan, Silugonggo sebesar 26,64\%; dan kesesuaian varietas padi untuk lahan tegalan yaitu varietas Inpago 5, Inpago 8, Inpago 9, Inpago 10, Inpago 11, Inpago 12 sebesar 26,35\%.

\section{DAFTAR PUSTAKA}

Ahadiyat, Y. R. dan Ardiansyah. 2020. Aplikasi Pemupukan Pada System of Rice Intensification Terhadap Pertumbuhan dan Hasil Padi Saat Musim Kemarau. Jurnal Penelitian Pertanian Terapan,20(2). pp. 213217.

Anda, Markus dan sarwani, S. 2012. Organic Carbon in Temperate Subsoils. Soil Science Society of America Journal, pp. 575-585.

Mulyani A., dan Dedi Nursyamsi, M. S. 2017. Strategi Pemanfaatan Sumberdaya Lahan untuk Pencapaian 
Basuki, B., dkk : Karakteristik Iklim dan Tanah Vulkanis di Sisi Barat Gunung Api Ijen Jawa Timur...

Swasembada Beras Berkelanjutan. Jurnal Sumberdaya Lahan, 11(1), pp. 11-22.

Balai Penelitian Tanah. 2009. Petunjuk Teknis Edisi 2, Analisis Kimia Tanah, Tanaman, Air, dan Pupuk. Balai Penelitian Tanah Deptan. Bogor.

BBPPMBTPH. 2021. Program Perluasan Areal Tanam Baru (PATB) Membawa Berkah bagi Petani. http://bbppmbtph.tanamanpangan.pertanian.go.id/index.php/berita/596. Diakses tanggal 6 Agustus 2021.

BPS. 2018. Luas Panen Padi Sawah Menurut Kabupaten/Kota di Provinsi Jawa Timur (ha), 2013-2017. BPS Provinsi Jawa Timur. https://jatim.bps.go.id./ (Diakses 9 April 2020)

BPS. 2019. Luas Panen, Produksi, dan Produktifitas Padi Menurut Kecamatan di Kabupaten Bondowoso (ha), 2018. BPS Kabupaten Bondowoso. https://bondowosokab.bps.go.id/ (Diakses 9 April 2020)

Basuki, Benito, Sunardipo, B.H, Yani S.N. 2015. Analisis Cluster Sebaran Hara Makro dan Rekomendasi Pemupukan untuk Tanaman Tebu ( Saccharum officinarum Linn .) Cluster Analysis of Macro Nutrient Distribution and Fertilization Recommendations for Sugarcane ( Saccharum officinarum Linn . Jurnal Ilmu Pertanian, 18(3), pp. 118-126.

Basuki, B. 2020. Pemetaan Tipologi Dan Kesesuaian Varietas Tanaman Tebu Berdasarkan Karakteristik Lahan Dan Tanah Di Jatiroto Lumajang. Buletin Tanaman Tembakau, Serat \& Minyak Industri, 12(1), pp34-44.

Basuki, B. and Sari, V. K. 2020. Efektifitas Dolomit Dalam Mempertahankan pH Tanah Inceptisol Perkebunan Tebu Blimbing Djatiroto. Buletin Tanaman Tembakau, Serat \& Minyak Industri, 11(2), pp. 58-64.

Dulbari, D. 2018. Karakter Agronomi dan Potensi Hasil 10 Genotipe Padi Tipe Baru pada Dua Lingkungan Tumbuh Berbeda. Jurnal Penelitian Pertanian Terapan, 18(1), p. 24.

Fuadi N.A., Purwanto M.Y.J., Tarigan.S.D., 2016. Kajian Kebutuhan Air Dan Produktivitas Air Padi Sawah Dengan Sistem Pemberian Air Secara Sri Dan Konvensional Menggunakan Irigasi Pipa. Jurnal Irigasi 11(1),pp.23-32.

Giamerti, Y. and Fauzan, A. 2018. Evaluasi tingkat kesesuaian katam terpadu pada komoditas padi di provinsi banten',Proseding, pp. 209-215.

Handani L.V., Wasino, Muntholib A., 2017. Dinamika Produksi Beras dan Pengaruhnya Terhadap Ketahanan Pangan Masyarakat di Kabupaten Grobogan Tahun 1984-1998. Journal of Indonesian History., 6(1), pp. 46-54.

Mahubessy, R. C. 2014. Tingkat Kesesuaian Lahan Bagi Tanaman Padi Berdasarkan Faktor Iklim Dan Topografi Di Kabupaten Merauke', Agrologia, 3(2), pp. 125-131.

Nasution, M. I. and Nuh, M. 2018. Kajian Iklim Berdasarkan Klasifikasi Oldeman Di Kabupaten Langkat', JISTech, 3(2), Proseding pp. 1-19.

Prasetyo, B., Suharta, N. And Yatno, E. 2009. Karakteristik Tanah-Tanah Bersifat Andik dari Bahan Piroklastis Masam di Dataran Tinggi Toba', Indonesian Soil and Climate Journal, (29), pp. 1-14.

Ritung, S., K. Nugroho, A. Mulyani, dan E. Suryani. 2011. Petunjuk Teknis Evaluasi Lahan Untuk Komoditas Pertanian (Edisi Revisi). Balai Besar Penelitian dan Pengembangan Sumberdaya Lahan Pertanian, Badan Penelitian dan Pengembangan Pertanian, Bogor. 168 hal

Rizkayanti, I., Syam, T. and Mahi, A. K. 2014. Evaluasi Kesesuaian Lahan Tanaman Padi Tadah Hujan pada 
Lahan Kelompok Tani Karya Subur', Agrotek Tropika, 2(1), pp. 165-169.

Ruskandar, A.Wahyuni, Nugroho, widyantorol. 2008. Preferensi Petani Terhadap Beberapa Varietas Unggul Padi (Studi Kasus di Kecamatan Kedung Tubah, Kabupaten Blora. Seminar Nasional Padi, pp. 13851393.

Sahulata, R. A. 2017. Perancangan Sistem Koleksi Data Lahan Tidur Dan Puso Untuk Peningkatan Produksi Komoditas Padi Dan Jagung. Gogoto Smart Journal. 3(2), pp. 249-263.

SUARJANA, I., SUPADMA, A. and ARTHAGAMA, I. 2016. Kajian Status Kesuburan Tanah Sawah Untuk Menentukan Anjuran Pemupukan Berimbang Spesifik Lokasi Tanaman Padi Di Kecamatan Manggis', E-Jurnal Agroekoteknologi Tropika (Journal of Tropical Agroecotechnology), 4(4), pp. 314-323.

Subhan dan Nurtika. 2004. Penggunaan Pupuk Fosfat, Kalium dan Magnesium pada Tanaman Bawang Putih Dataran Tinggi', Jurnal Ilmu Pertanian, 11(2), pp. 56-67.

Sukarman, S., Dariah, A. and Suratman, S. 2020. Tanah Vulkanik Di Lahan Kering Berlereng Dan Potensinya Untuk Pertanian Di Indonesia . Jurnal Penelitian Dan Pengembangan Pertanian, 39(1), P. 21-34.

Sukri, M. Z. Firgiyanto R., Sari V.K., Basuki. .2020. Kombinasi Pupuk Kandang Sapi, Asam Humat Dan Mikoriza Terhadap Infeksi Akar Bermikoriza Tanaman Cabai Dan Ketersediaan Unsur Hara Tanah Udipsamments', Jurnal Penelitian Pertanian Terapan, 19(2), P. 142

Supriyadi, Sri Hartati, A. A. 2019. Kajian Pemberian Pupuk P, Pupuk Mikro Dan Pupuk Organik Terhadap Serapan P Dan Hasil Kedelai (Glycine Max L.) Varietas Kaba Di Inseptisol Gunung Gajah Klaten. Journal Of Chemical Information And Modeling, 53(9), Pp. 1689-1699.

Suratman, Hikmatullah and Sulaiman, A. A. 2018. Karakteristik Tanah-Tanah dari Bahan Induk Abu Volkan Muda di Jawa Barat dan Jawa Tengah. Jurnal Tanah dan Iklim, 42(1), pp. 1-12.

Tampubolon K., Razali., Guchi H., 2015. Evaluasi Kesesuaian Lahan Tanaman Padi Sawah Irigasi (Oryza sativa L.) Di Desa Bakaran Batu Kecamatan Sei Bamban Kabupaten Serdang Bedagai. Jurnal Online Agroekoteaknologi, 3(2).pp. 732-739.

Wahyuni E.T, Triyono S., Suherman. 2012. Penentuan Komposisi Kimia Abu Vulkanik Dari Erupsi Gunung Merapi. Jurnal Manusia dan Lingkungan, 19(2), pp. 150-159.

Wihardjaka dan Poniman, 2015. Kontribusi Hara Sulfur terhadap Produktivitas Padi dan Emisi Gas Rumah Kaca di Lahan Sawah (Contribution of Sulfur to Rice Productivity and Atmospheric Greenhouse Gases in Lowland). Jurnal Iptek Tanaman Pangan, 10(1), pp.9-17

Yopie Priest Aulia Sinaga, Razali, M. S. And Program .2014. Evaluasi Kesesuaian Lahan Untuk Padi Sawah Tadah Hujan (Oryza Sativa L.) Di Kecamatan Muara Kabupaten Tapanuli Utara. 2(Hal 140), Pp. 1042 1048.

Yuniartha, L. 2020. Penurunan Produksi Beras Nasional Secara Berturut-Turut Mengkhawatirkan. Kontan.Co.Id. Diakses Tanggal 9 April 2020 Pukul 19.08 Wib.

Yuniarti A, Damayani M., Nur D.M., 2019. Efek Pupuk Organik Dan Pupuk N,P,K Terhadap C-Organik, NTotal, C/N, Serapan N, Serta Hasil Padi Hitam Pada Inceptisols. Jurnal Pertanian Presisi, 3(2),Pp.90105.

Yusuf, M. F. Siahaan, Sukiyah, Mulyo. 2018. Bendungan Parigi The Slope Efect Toward Sementation Rate On Parigi Dam Plan. Bulletin Of Scientific Contribution 16, pp. 89-100. 
Basuki, B., dkk : Karakteristik Iklim dan Tanah Vulkanis di Sisi Barat Gunung Api Ijen Jawa Timur...

Zaennudin, A. Deden Wahyudin, Mamay Sumardi, E. Kusdinar. 2012. Prakiraan bahaya letusan Gunung Api Ijen Jawa Timur. Jurnal Lingkungan dan Bencana Geologi, 3(2), pp. 109-132. 